\title{
The Reality of Strategic Thinking Practice at the Faculty of Education, Damietta University: A Faculty Perspective
}

\author{
Mayada M. Al-Basel \\ Professor of Foundations of Education \\ Department of Foundations of Education, Damietta University \\ P.O. Box 34517, Damietta, Egypt \\ E-mail: mayadaalbasel5@gmail.com
}

\begin{abstract}
Hanaa I. Soliman
Associate Professor of Foundations of Education, Damietta University

P.O. Box 34517, Damietta, Egypt

E-mail: hanaasoliman16@yahoo.com
\end{abstract}

Received: July 5, 2020 Accepted: August 10, 2020 Published: August 17, 2020

doi:10.5296/jei.v6i2.17319ＵRL: https://doi.org/10.5296/jei.v6i2.17319

\begin{abstract}
The present study aims at investigating the reality of strategic thinking practice at the Faculty of Education, Damietta University from the perspective of the faculty members. It adopted the descriptive approach and utilized a ten-domain questionnaire. The results showed that although the Faculty has an approved strategic plan and a quality assurance unit, the mechanisms of following up the implementation of the strategic plan are inadequate. Moreover, the Faculty's quality assurance unit has not developed integrated databases of its various activities. The study recommended that the Council of the Faculty of Education should make and follow up the implementation of an updated and approved action plan. Training courses on the specifications and making reports of the educational programs, syllabi, etc. should be offered to the faculty members. Additionally, integrated databases of the various activities of the Faculty's quality assurance unit should be developed.
\end{abstract}

Keywords: Strategic thinking, Faculty members, Faculty of Education, Damietta University 


\section{Introduction}

The contemporary strategic features require rethinking of the exercise of leadership in terms of style, thinking, and practice. Leaders capable of thinking strategically in this ever-changing age are urgently needed. Universities, as key community organizations, deviate their mission and benefit if they do not meet future needs. Therefore, they need skillful leaders who can cope with permanent change and reality according to the universities' goals and roles. In short, the contemporary knowledge and technology revolution requires leaders who master strategic thinking (Ashammari \& Akhras, 2017).

Strategic thinking is an important contemporary approach to the management of universities. It motivates creative and innovative ideas and imagination. Moreover, it achieves positive results in increasing efficiency and achieving their competitiveness (Al-Amiri \& Kassir, 2017, p. 56). Adopting strategic thinking helps universities continue to progress, overcome obstacles, and develop appropriate solutions to their problems. It is also an environmentally appropriate method to maintain sustainability (El-Balawi, 2016).

\subsection{Concept of Strategic Thinking}

Strategic thinking is a creative activity and an intellectual, holistic, multi-dimensional planning path that investigates the various domains and manifestations of reality, draws future visions, and develops practical programs and plans to achieve the desired future (Al'Attar \& Afifi, 2017, p. 33). It is a sense, perception, and deep vision of the future, while not neglecting the past. Moreover, it is an invisible synthetic process, which leads to the development of strategies and taking steps to lead the institution to a better reality (Al-Amiri \& Kassir, 2017).

\subsection{Aims of Strategic Thinking}

Strategic thinking aims to predict challenges, situations, and conditions to build and develop the organization's strategic foresight capacity by analyzing various future scenarios (Dushkov, 2018). It improves "organizational performance through innovation and creative activities that enhance overall leadership effectiveness" (Muriithi, Louw, \& Radloff, 2018, p. 2). It helps leaders to gain insight and develop problem-solving skills. Moreover, it increases their perception, imagination, interpretation, and surveying the environment for important information. It helps them identify opportunities and perceive emerging conditions to achieve long-term competitiveness (Al'Attar \& Afifi, 2017, p. 33).

\subsection{Importance of Strategic Thinking}

Strategic thinking enables a manager to know the effective factors in achieving objectives and why and how to create value to the customer? (Emran \& Emamgholizadeh, 2015). It improves the quality of professional life. It is a necessity to address the problems facing universities in creative ways that allow them to achieve excellence and pursue updates in their fields by investing resources, knowledge, and skills (Al-Hamdani \& Al-Khulani, 2018, p. 213). Thus, strategic thinking results in proper planning. Strategic thinking at university helps define, set, and disseminate priorities among the faculty members and staff; develops the 
ability to shape the future and achieve goals; develops vision; reduces the error rate in handling situations and problems. Moreover, it is crucial for continuous development and modernization of university performance. It helps handle events and facts and improve the university's ability to manage time with the appropriate readiness of intellectual, material, and human potentials.

Strategic thinking is harmonic. It combines material and spiritual factors. It is futuristic as it builds on the past and present to predict the future. It is philosophical and creative because it maintains the competitiveness of the university using new ideas. It controls the internal and external effects. It is also concerned with collecting, reshaping, and developing the views and laws governing the work, in accordance with the leadership's cooperation and the participation of the staff to come up with the best solutions, promote the final product, achieve modernization and renewal, and facilitate the emergence of ambitious goals (Ashammari \& Akhras, 2017).

\subsection{Domains of strategic thinking}

Alebbini (2018) Khalafallah (2015) argue that strategic thinking can be used in different university domains, including:

(1) Creativity: It refers to how individuals handle problems and choose appropriate solutions. It also refers to individuals' ability to integrate available ideas to come up with a new combination and composition. Therefore, creativity relates to the ability of leadership to introduce and adopt new and original ideas and direct positive behavior towards promoting work.

(2) Accountability: It happens when the leaders have systems and regulations to transparently define the terms of accountability and possess mechanisms of reward and punishment accordingly.

(3) Future vision: It means the power of conceptual perception of the future. Therefore, officials must have a future vision according to which the stages of work and achievement are determined, while convincing the faculty members and staff, considering reality, and providing mechanisms to implement the objectives of this vision.

(4) Conflict management: It is the ability of the leader to resolve all conflicts between the faculty and the staff using appropriate strategies while trying to achieve justice and maintain transparency.

(5) Intelligence: The leader should be intelligent, intuitive, logical, and diplomatic when making decisions and forming organizational structures, with the ability to use conscious analytical thinking.

(6) Systematic thinking: It is the ability to install and assemble different elements to achieve university objectives. Thus, the various parts are studied in terms of relationship to serve the objectives and to address the departments as subsystems within the main system. 
(7) Diverse mental pattern: It is about adopting modern scientific methods and conducting regular studies to develop work.

\subsection{Elements of Strategic Thinking}

According to Elfarra (2009), strategic thinking has the following five elements:

(1) Systems' perspective: A strategic thinker looks at the organization comprehensively. Any change in any aspect of the organization affects all other aspects.

(2) Target-centered thinking: It is thinking about the organization's mission and strategic goals, not to be distracted by any future changes. It directs the staff of the organization to focus on achieving its targets.

(3) Thinking about the future of the organization promptly: It is based on defining the desired future. The strategy is influenced not only by the future but by the existing strategic gap between current reality and moving towards the future, as well. However, the traditional view focuses on the degree of coherence between the available resources and opportunities.

(4) Hypothesis-driven: Strategic thinking is based on dealing with the vast amount of information about the various accelerating variables and the surrounding environmental conditions, as well as developing convincing hypotheses related to economic, technological, competitive, and other factors in order to develop strategies that fit with these hypotheses.

(5) Intelligent opportunity: Strategic thinking is based on openness to new experiences and strategies that may be more appropriate. This aspect is necessary to adapt to the rapid continuous changes.

\subsection{Patterns of Strategic Thinking}

Ashammari and Akhras (2017) argue that there are various strategic thinking patterns. For example, holistic thinking is the pattern of thinking that is concerned with defining the general framework of the problem based on the experience of the leader with regard to understanding and analyzing problems. Abstract thinking is concerned with identifying the relevant factors and making adequate decisions. Diagnostic thinking is based on analyzing the administrative situation, diagnosing the reasons for decision-making, and choosing alternatives to conclude inevitable solutions. Schematic thinking is a pattern of thinking to identify potential results, then developing items to conclude results.

\subsection{Strategic Thinking Among Leaders}

It is the responsibility of the leaders to provide the future vision of the university through tracking the new aspects of change in terms of speed and intensity internally and externally. Each university has ingredients of success and failure, but universities differ in terms of utilizing such ingredients. Accordingly, the success of strategic thinking depends on the commitment of the university's high administration in adopting it in order to improve competitiveness (El-Balawi, 2016). The practice of strategic thinking comprises analysis, 
synthesis, and formulation of the mission, vision, strategic objectives, and strategy. It also covers implementing and applying the strategy in addition to strategic review and evaluation (Alasmar, 2007)

According to Elanzi and Akhras (2010), the lack of strategic thinking at the university gives rise to many issues, e.g., missing many opportunities to benefit from the available things in the external environment, encountering many problems and crises because of the lack of early awareness of the constraints and threats in the external environment. It also causes losing parts of the potentials and resources, it creates a weak relationship between the mission and objectives, on one hand, and the policies, rules of action, and some decisions, on the other. It causes unclear bases and criteria for performance evaluation due to the inability to turn the goals into measurable objective results, plans, and programs. The university may be unable to come up with important innovations. Moreover, the organizational environment can be characterized by tension, anxiety, insecurity, and lack of belonging. The university may make confused decisions and has clear gaps between its promises, commitments, and setting objectives that are difficult to achieve. The university leaders cannot find appropriate strategic alternatives in response to changes or surprises that occur in the university environment and require modification or change of work paths. Additionally, some categories of the university community may feel dissatisfied with the university.

The leaders' strategic thinking can be developed by training, including establishing the belief in the importance of thinking, respecting the mind and its role in creativity, selecting persons who can practice complex mental processes, as well as running training programs on meditation, conceptualization, and looking to the future (Mohamed, 2011). The development of strategic thinking requires shifting from the administrative thinking about problem-solving to a strategic thinking activity based on identifying problems, finding and exploring opportunities, generating alternative solutions, and defining the most appropriate strategic option according to understanding and analysis of the strategic situation, as well as the knowledge obtained from experience. Accordingly, executive management becomes strategic (Al-Khara'an, 2018).

Alebbini (2018) argues that developing strategic thinking among the leaders, faculty, and staff of the university requires active listening to all members in work and meetings by offering them, especially the creative ones, with opportunities to express their opinions and generate ideas. They should be allowed to formulate the university strategy, vision, mission, values, and objectives to gain trust, respect, and cooperation. Additionally, relevant training programs and workshops should run to demonstrate that leadership is a collective responsibility. Dushkov (2018) reports some basic trends for leaders to become strategic thinkers, including continuous learning about the university and its internal and external conditions to be prepared for unexpected situations, identifying the needs and priorities, and achieving basic organizational priorities within the university.

Because of the importance of strategic thinking, in general, and among leaders, in particular, it was addressed by many studies in terms of concept, development, and relationship to several variables. For example, Aly (2018) explored the degree of practicing strategic 
thinking patterns (comprehensive, abstract, diagnostic, and planning) among the heads of academic departments at Tikrit University. The results showed that the participants were interested in thinking patterns. Minor differences were reported among the humanities and scientific colleges. Young (2016) sought a more comprehensive understanding of strategic thinking. Since the end of the Vietnam War, there was a consistent attitude to link strategic thinking with the proper use of strategy. Accordingly, leaders aim to achieve competitiveness in the future.

Goldman, Scott, and Follman (2015) examined the most important practices that organizations follow to develop strategic thinking among the staff. The results showed that organizations use a limited range of thinking development methods and much indirect development support through general leadership programs. Alaly (2014) explored the degree of practicing strategic thinking styles among heads of academic departments at applied colleges in Kuwait and its relationship with re-engineering of administrative processes from the perspective of faculty members. Nuntamanop, Kauranen, and Igel (2013) introduced new insights into strategic thinking and proposed a model of the (strategic thinking competency). The study concluded seven characteristics of strategic thinking that affect strategy formulation, strategic actions, and business performance, namely conceptual thinking ability, visionary thinking, creativity, analytical thinking, synthesizing ability, objectivity, and learning.

Almarshad (2013) conducted a field study to highlight the practices and application of strategic thinking, stressing the focus on the organization's size and nature of work. He also stressed the need to identify the percentage and degree of understanding and comprehension to apply the concept and exercises of strategic thinking. Haycock, Cheadle, and Bluestone (2012) reported that strategic thinking could be used in any organization seeking competitiveness with a focus on creativity and innovation. Moreover, organizational leaders are responsible for implementing strategic thinking to address competition and change in the present marketplace. Leaders of libraries can take advantage of strategic thinking to achieve higher levels and a new successful future.

Monnavarian, Farmani, and Yajam (2011) aimed to measure the ability to strategic thinking by its application among strategic leaders. The results showed that leaders are ready to apply the factors of strategic thinking to leadership. Steptoe-Warren, Howat, and Hume (2011) reviewed the literature of strategic thinking and decision-making by examining both administrative and psychological literature on strategic decision-making, with particular emphasis on factors that influence strategic decision-making. The literature review revealed that management cognition and individual values could affect strategic decision-making. Strategic competencies are important, although there is no agreement on them.

Pisapia and Robinson (2010) implemented the Strategic Thinking Protocol (STP), which demonstrates a new planning method called Strategic Thinking to handle external pressures for change. The STP framework uses the core capabilities of strategic thinking skills, strategic sensitivity, value specification, strategic conversations, minimum specifications, and strategic fitness to develop a practical plan in the Department of Educational Leadership and 
the Faculty of Education and to compare the results to the traditional strategic planning effort employed at the university level. The literature shows that strategic thinking has an important role in making the future, handling external pressures, drawing effective strategies for the advancement of institutions, and achieving competitiveness.

\subsection{Introduce the Problem}

Colleges of education, with their various roles and functions, are the basis for the development of education at all stages. Teacher preparation and development is a top priority. Moreover, good training of the teacher develops pre-university education, whose outputs are the inputs of higher education. Therefore, achieving human development depends on the quality of education. Egypt has paid a clear interest in the development of the colleges of education and has dedicated several development projects for them centrally and locally. Their development has become one of the most important projects in higher education. They are developed by including all components, starting from defining vision and tasks to achieving total quality (Ministry of Higher Education, 2005).

Damietta University is higher education in Egypt. It began with opening classes for some faculties of Mansoura University in Damietta. Then, the decisions to set up the branch colleges were based on the regulations of the corresponding faculties at Mansoura University. For example, the Faculty of Education in Damietta was established pursuant to the ministerial decision No. (1142) on 25 November 1976. In 2007, the presidential decree No. (276) was issued to set up a branch in Damietta. In July 2012, the presidential decree No. (19) of 2012 to establish Damietta University in New Damietta was issued (Damietta University, 2015).

The Faculty of Education, Damietta University seeks to achieve its vision "to become a university institution that seeks total quality in the preparation of teachers, specialists, and researchers in order to achieve sustainable human and community development" (Faculty of Education, Damietta University, 2019a). It qualifies teachers to compete and be compatible with knowledge society, technological development, and modern trends in teaching and learning. It also motivates educational research by upgrading its programs and units and responding to the needs and educational problems of the community through providing specialized technical services and consultations (Faculty of Education, Damietta University, 2019b). The Faculty of Education has set the following strategic objectives:

(1) Developing the Faculty's infrastructure and maximizing the utilization of its material and human resources;

(2) Developing existing academic undergraduate and postgraduate programs in accordance with the standards of the National Authority for Quality Assurance and Accreditation in Education and the requirements of the labor market;

(3) Creating an active curricular and extracurricular learning environment to maximize the use of students' potential and talents;

(4) Developing the scientific research system in the light of competition trends and upgrading its qualitative and quantitative outputs; 
(5) Developing new academic programs that meet the needs of the society and the labor market; and

(6) Developing community service and environment development programs and activities by maximizing the utilization of the material and human resources (Faculty of Education, Damietta University, 2019c).

Thus, leaders that adopt strategic thinking should be recruited. Strategic thinking should be activated to confront future challenges by setting active strategies (Al-Hamdani and Al-Khulani, 2018). The problem of the study was defined in raising the following major question: What is the reality of strategic thinking practice at the Faculty of Education, Damietta University from the perspective of the faculty members?

\subsection{Objective}

The study aims to identify the reality of strategic thinking practice at the Faculty of Education, Damietta University from the perspective of the faculty members.

\subsection{Significance}

The present study is significant because it addresses an important issue that can be utilized at the Faculty of Education, Damietta University to meet future needs and achieve satisfaction among the staff and the community. It explores a relatively modern management concept, i.e. strategic thinking, which can help universities become more successful and competitive. It can help academic and administrative leaders develop visions to keep pace with changes in the field of education. Moreover, the results and recommendations benefit scientific research and draw the attention of those in charge of administrative work to strategic thinking. The results can benefit administrative leaders and faculty members.

\subsection{Limitations}

\subsubsection{Human Limitations}

The study was limited to a sample of the faculty members (professor, assistant professor, and lecturer).

\subsubsection{Spatial Limitations}

The study was conducted at the Faculty of Education, Damietta University, Egypt.

\subsubsection{Temporal Limitations}

The study was conducted in the first semester of 2018/2019.

\subsubsection{Subject Limitations}

The study investigated the practice of strategic thinking at the Faculty of Education, Damietta University.

\subsection{Definition of Terms}

The authors define strategic thinking as a comprehensive, planning, and multi-perspective 
thinking stream based on studying reality, generating future perspectives, and developing practical plans and programs to achieve the desired future of the Faculty of Education. It analyzes the internal and external environments, prepares alternative scenarios, discusses and analyzes the future scenarios, and makes decisions regarding the policies and strategies of the Faculty of Education.

\section{Methodology}

\subsection{Method}

The present study uses the descriptive approach because it is appropriate for exploring the social and human phenomena, as well as the nature of the study.

\subsection{Population and Sampling}

The population of the study covered the faculty members of the Faculty of Education, Damietta University, as shown in Table 1.

Table 1. The faculty members of the Faculty of Education, Damietta University (Damietta University, 2019)

\begin{tabular}{|l|l|l|l|l|l|l|l|}
\hline Degree/Department & $\begin{array}{l}\text { Professor } \\
\text { Emeritus }\end{array}$ & Professor & $\begin{array}{l}\text { Assistant } \\
\text { Professor } \\
\text { Emeritus }\end{array}$ & $\begin{array}{l}\text { Assistant } \\
\text { Professor }\end{array}$ & $\begin{array}{l}\text { Lecturer } \\
\text { Emeritus }\end{array}$ & Lecturer & Total \\
\hline Foundations of Education & 3 & 2 & 1 & 4 & 1 & 4 & 15 \\
\hline Curriculum \& Instruction & 6 & 4 & - & 6 & 2 & 10 & 28 \\
\hline Psychology & 1 & 2 & 5 & 3 & - & 5 & 16 \\
\hline Educational Technology & - & 2 & - & 3 & - & 7 & 12 \\
\hline Kindergarten & - & - & - & 2 & - & 4 & 6 \\
\hline Total & 10 & 10 & 6 & 18 & 3 & 30 & 77 \\
\hline
\end{tabular}

A questionnaire was distributed to a randomly selected sample of (50) faculty members. Only 39 questionnaires were valid for statistical processing (the sample of the study).

\subsection{Tool}

\subsubsection{Preparation}

Because of the nature of the study in terms of objectives, method, and population, the questionnaire was used to collect data. This questionnaire was developed based on the problem, objectives, questions, and literature.

\subsubsection{Aim of the Questionnaire}

The questionnaire distributed to the faculty members of the Faculty of Education, Damietta University aimed to identify the reality of practicing strategic thinking at the Faculty from 
their perspective. It consisted of two parts. While Part I comprised the preliminary data of the participants (namely department and academic degree), Part II covered the domains. Each participant selects the most important three practices that support the practice of strategic thinking at the Faculty, as follows: Strengths (11 items), weaknesses (12 items), opportunities ( 6 items), threats ( 8 items), issues to be addressed over the next two years ( 7 items), personal objectives (an open-ended question), services and works presented to employees and community ( 5 items), internal-external information ( 8 items), promotion of distinguished persons (an open-ended question), and new services and programs ( 7 items).

\subsubsection{Validity of the Questionnaire}

The preliminary draft of the questionnaire was presented to (11) professors of education to verify the validity, applicability, and clarity of the items. Then, modifications were made to some items, and others were deleted to have the final form of the questionnaire.

\subsection{Statistical Processing}

To analyze the data of the study, frequencies and percentages were employed to identify the three most important domains on which the participants agreed.

\section{Results}

\subsection{Strengths of the Faculty of Education, Damietta University}

Table 2. Frequencies and percentages of the responses to (the three most important strengths of the Faculty of Education, Damietta University)

\begin{tabular}{|c|c|c|c|c|c|c|c|}
\hline \multirow{3}{*}{ No. } & \multirow{3}{*}{ Strengths } & \multicolumn{6}{|c|}{ Rank } \\
\hline & & \multicolumn{2}{|c|}{ First } & \multicolumn{2}{|c|}{ Second } & \multicolumn{2}{|c|}{ Third } \\
\hline & & Frequency & $\%$ & Frequency & $\%$ & Frequency & $\%$ \\
\hline 1 & The Faculty has a strategic plan approved by the Faculty Council. & 27 & 69.2 & 1 & 2.6 & 0 & 0 \\
\hline 2 & The Faculty contains a quality assurance unit. & 0 & 0 & 26 & 66.7 & 1 & 2.6 \\
\hline 3 & $\begin{array}{l}\text { The Faculty has qualified human cadres in the field of quality } \\
\text { assurance. }\end{array}$ & 6 & 15.4 & 4 & 10.3 & 2 & 5.1 \\
\hline 4 & The Faculty has a website. & 1 & 2.6 & 5 & 12.8 & 4 & 10.3 \\
\hline 5 & $\begin{array}{l}\text { The Faculty has concluded cooperation protocols with some civil } \\
\text { society institutions. }\end{array}$ & 1 & 2.6 & 1 & 2.6 & 4 & 10.3 \\
\hline 6 & $\begin{array}{l}\text { The students are notified with the results of exams using the } \\
\text { Farabi system. }\end{array}$ & 2 & 5.1 & 1 & 2.6 & 5 & 12.8 \\
\hline 7 & $\begin{array}{l}\text { The students evaluate the performance of the faculty using the } \\
\text { Farabi system. }\end{array}$ & 2 & 5.1 & 1 & 2.6 & 1 & 2.6 \\
\hline 8 & The website of the Faculty displays various services. & 0 & 0 & 0 & 0 & 22 & 56.4 \\
\hline
\end{tabular}

Table 2 shows the three most important strengths of the Faculty of Education, Damietta University.

(a) The Faculty has a strategic plan approved by the Faculty Council. 
(b) The Faculty contains a quality assurance unit.

(c) The website of the Faculty displays various services.

\subsection{Shortcomings and Weaknesses at the Faculty of Education}

Table 3. Frequencies and percentages of the responses to (the three most important shortcomings and weaknesses at the Faculty of Education that should be accurately identified and urgently addressed

\begin{tabular}{|c|c|c|c|c|c|c|c|}
\hline \multirow{3}{*}{ No. } & \multirow{3}{*}{ Shortcomings \& Weaknesses } & \multicolumn{6}{|c|}{ Rank } \\
\hline & & \multicolumn{2}{|l|}{ First } & \multicolumn{2}{|c|}{ Second } & \multicolumn{2}{|c|}{ Third } \\
\hline & & Frequency & $\%$ & Frequency & $\%$ & Frequency & $\%$ \\
\hline 1 & $\begin{array}{l}\text { The Faculty of Education lacks mechanisms to follow up the } \\
\text { implementation of the strategic plan. }\end{array}$ & 24 & 61.5 & 1 & 2.6 & 1 & 2.6 \\
\hline 2 & $\begin{array}{l}\text { The Quality Assurance Unit at the Faculty has not established } \\
\text { integrated databases on its various activities. }\end{array}$ & 4 & 10.3 & 23 & 59 & 0 & 0 \\
\hline 3 & The Faculty does not hold its own scientific conference regularly. & 2 & 5.1 & 2 & 5.1 & 2 & 5.1 \\
\hline 4 & $\begin{array}{l}\text { The Faculty of Education does not provide the Quality Assurance } \\
\text { Unit with adequate resources and equipment to carry out its } \\
\text { activities adequately. }\end{array}$ & 2 & 5.1 & 2 & 5.1 & 1 & 2.6 \\
\hline 5 & $\begin{array}{l}\text { The scientific departments at the Faculty of Education have not } \\
\text { been informed of the Academic References Standards (ARS). } \\
\text { Accordingly, their programs and courses have not been specified } \\
\text { in accordance. }\end{array}$ & 1 & 2.6 & 0 & 0 & 2 & 5.1 \\
\hline 6 & $\begin{array}{l}\text { The Faculty of Education does not apply the academic support } \\
\text { system (academic excellence and office hours). }\end{array}$ & 0 & 0 & 2 & 5.1 & 1 & 2.6 \\
\hline 7 & $\begin{array}{l}\text { The Faculty of Education does not have effective mechanisms to } \\
\text { raise awareness of the ethics of scientific research and follow up } \\
\text { its application. }\end{array}$ & 1 & 2.6 & 2 & 5.1 & 1 & 2.6 \\
\hline 8 & $\begin{array}{l}\text { The Faculty of Education does not have any data on the research } \\
\text { projects funded by local, regional, and international institutions. }\end{array}$ & 0 & 0 & 2 & 5.1 & 1 & 2.6 \\
\hline 9 & $\begin{array}{l}\text { The Faculty of Education does not use effective means to } \\
\text { encourage and support the participation of the faculty members, } \\
\text { teaching assistants, and students in activities, projects, and } \\
\text { scientific conferences. }\end{array}$ & 4 & 10.3 & 2 & 5.1 & 22 & 56.4 \\
\hline 10 & There is no certified alumni association. & 0 & 0 & 0 & 0 & 1 & 2.6 \\
\hline 11 & $\begin{array}{l}\text { The Faculty of Education does not have defined mechanisms to } \\
\text { handle education problems. }\end{array}$ & 1 & 2.6 & 2 & 5.1 & 2 & 5.1 \\
\hline 12 & The Faculty of Education cannot diversify its financial resources. & 0 & 0 & 1 & 2.6 & 5 & 12.8 \\
\hline
\end{tabular}

Table 3 shows the three most important shortcomings and weaknesses that should be accurately identified and urgently addressed at the Faculty of Education, Damietta University, as follows:

(a) The Faculty of Education lacks mechanisms to follow up the implementation of the strategic plan. 
(b) The Quality Assurance Unit at the Faculty has not established integrated databases on its various activities.

(c) The Faculty of Education does not use effective means to encourage and support the participation of the faculty members, teaching assistants, and students in activities, projects, and scientific conferences.

\subsection{Opportunities for the Faculty of Education Over the Next Two Years}

Table 4. Frequencies and percentages of the responses to (the three most important opportunities for the Faculty of Education over the next two years)

\begin{tabular}{|c|c|c|c|c|c|c|c|}
\hline \multirow{3}{*}{ No. } & \multirow{3}{*}{ Opportunities } & \multicolumn{6}{|c|}{ Rank } \\
\hline & & \multicolumn{2}{|l|}{ First } & \multicolumn{2}{|c|}{ Second } & \multicolumn{2}{|c|}{ Third } \\
\hline & & Frequency & $\%$ & Frequency & $\%$ & Frequency & $\%$ \\
\hline 1 & $\begin{array}{l}\text { The state encourages the development of distinguished } \\
\text { programs. }\end{array}$ & 27 & 69.2 & 0 & 0 & 4 & 10.3 \\
\hline 2 & $\begin{array}{l}\text { The representation of stakeholders in the Faculty Council should } \\
\text { be employed. }\end{array}$ & 1 & 2.6 & 1 & 2.6 & 1 & 2.6 \\
\hline 3 & Increased demand for university education & 4 & 10.3 & 1 & 2.6 & 0 & 0 \\
\hline 4 & $\begin{array}{l}\text { The exchange of experience with some concerned bodies (Adult } \\
\text { Education Authority and the Literacy Project at the Faculty) } \\
\text { should be employed. }\end{array}$ & 3 & 7.7 & 7 & 17.9 & 0 & 0 \\
\hline 5 & $\begin{array}{l}\text { Competitive projects for scientific research and funded by } \\
\text { scientific institutions should be utilized. }\end{array}$ & 2 & 5.1 & 7 & 17.9 & 24 & 61.5 \\
\hline 6 & $\begin{array}{l}\text { Cultural agreements with local or international bodies should be } \\
\text { employed. }\end{array}$ & 2 & 5.1 & 23 & 59 & 10 & 25.6 \\
\hline
\end{tabular}

Table 4 illustrates the three most important opportunities for the Faculty of Education over the next two years, as follows:

(a) The state encourages the development of distinguished programs.

(b) Cultural agreements with local or international bodies should be employed.

(c) Competitive projects for scientific research and funded by scientific institutions should be utilized. 


\subsection{Threats and Challenges Facing the Faculty of Education}

Table 5. Frequencies and percentages of the responses to (the three most serious threats and challenges facing the Faculty of Education that could affect the ability to provide better services to the employees and the surrounding community)

\begin{tabular}{|l|l|l|l|l|l|l|l|}
\hline \multirow{2}{*}{ No. } & \multirow{2}{*}{ Threats \& Challenges } & \multicolumn{5}{|c|}{ Rank } \\
\cline { 3 - 8 } & & \multicolumn{2}{|c|}{ First } & \multicolumn{2}{|c|}{ Second } & \multicolumn{2}{c|}{ Third } \\
\cline { 3 - 9 } & Frequency & $\%$ & Frequency & $\%$ & Frequency & $\%$ \\
\hline 1 & Decommissioning the graduates of the Faculty of Education & 32 & 82.1 & 3 & 7.7 & 0 & 0 \\
\hline 2 & Weak budgets allocated for various fields of the Faculty & 3 & 7.7 & 4 & 10.3 & 3 & 7.7 \\
\hline 3 & $\begin{array}{l}\text { Current events and the resulting economic, social, and scientific } \\
\text { challenges }\end{array}$ & 1 & 2.6 & 0 & 0 & 1 & 2.6 \\
\hline 4 & $\begin{array}{l}\text { Failure to achieve the required level of quality to obtain } \\
\text { accreditation }\end{array}$ & 1 & 2.6 & 5 & 12.8 & 0 & 0 \\
\hline 5 & $\begin{array}{l}\text { Low achievement of students enrolled in the Faculty after } \\
\text { completing the general secondary school }\end{array}$ & 2 & 5.1 & 27 & 69.2 & 4 & 10.3 \\
\hline 6 & $\begin{array}{l}\text { Recruitment of the faculty members, especially the outstanding } \\
\text { ones, by Arab and foreign universities }\end{array}$ & 0 & 0 & 0 & 0 & 27 & 69.2 \\
\hline 7 & High regional and global competitiveness & 0 & 0 & 0 & 0 & 2 & 5.1 \\
\hline 8 & The dissatisfaction of the faculty members with their incomes & 0 & 0 & 0 & 0 & 2 & 5.1 \\
\hline
\end{tabular}

Table 5 illustrates the three most important threats and challenges facing the Faculty of Education, as follows:

(a) Decommissioning the graduates of the Faculty of Education.

(b) Low achievement of students enrolled in the Faculty after completing the general secondary school.

(c) Recruitment of the faculty members, especially the outstanding ones, by Arab and foreign universities. 
3.5 Issues That the Faculty Should Focus on to Accomplish Over the Next Two Years

Table 6. Frequencies and percentages of the responses to (the three most important issues that the Faculty should focus on to accomplish over the next two years)

\begin{tabular}{|l|l|l|l|l|l|l|l|}
\hline \multirow{2}{*}{ No. } & \multirow{2}{*}{ Issues } & \multicolumn{5}{|c|}{ Rank } \\
\cline { 3 - 8 } & & \multicolumn{2}{|c|}{ First } & \multicolumn{3}{|c|}{ Second } & \multicolumn{2}{c|}{ Third } \\
\cline { 3 - 9 } & Frequency & $\%$ & Frequency & $\%$ & Frequency & $\%$ \\
\hline 1 & Developing outstanding programs & 25 & 64.1 & 3 & 7.7 & 1 & 2.6 \\
\hline 2 & $\begin{array}{l}\text { Sustainable professional development of the faculty members } \\
\text { and the assistants, as well as the services provided to them }\end{array}$ & 7 & 17.9 & 6 & 15.4 & 1 & 2.6 \\
\hline 3 & Developing the efficiency of the administrative system & 0 & 0 & 3 & 7.7 & 3 & 7.7 \\
\hline 4 & Diversifying funding sources and rationalizing expenditure & 0 & 0 & 3 & 7.7 & 1 & 2.6 \\
\hline 5 & Accreditation of the programs offered at the Faculty & 6 & 15.4 & 24 & 61.5 & 6 & 15.4 \\
\hline 6 & $\begin{array}{l}\text { Partnership between the Faculty, community institutions, and } \\
\text { competent authorities }\end{array}$ & 1 & 2.6 & 0 & 0 & 3 & 7.7 \\
\hline 7 & $\begin{array}{l}\text { Stimulating excellence in educational scientific research and } \\
\text { international publishing }\end{array}$ & 0 & 0 & 0 & 0 & 24 & 61.5 \\
\hline
\end{tabular}

Table 6 shows the three most important issues that the Faculty should focus on to accomplish over the next two years, as follows:

(a) Developing outstanding programs.

(b) Accreditation of the programs offered at the faculty.

(c) Stimulating excellence in educational scientific research and international publishing.

\subsection{Personal Goals of the Faculty Members}

Responses showed that the participants seek to achieve the following goals this year: Participating in research projects for the advancement of the Faculty, preparing scientific research for international publication, activating the electronic scoring system, and establishing question banks for educational courses. 


\subsection{Services Provided by the Faculty to Its Employees and the Surrounding Community}

Table 7. Frequencies and percentages of the responses to (the three most important services provided by the Faculty to its members and the surrounding community and need improvement)

\begin{tabular}{|l|l|l|l|l|l|l|l|}
\hline \multirow{2}{*}{ No. } & \multirow{2}{*}{ Services and Works } & \multicolumn{5}{|c|}{ Rank } \\
\cline { 3 - 9 } & & \multicolumn{2}{|c|}{ First } & \multicolumn{2}{|c|}{ Second } & \multicolumn{2}{c|}{ Third } \\
\cline { 3 - 10 } & & Frequency & $\%$ & Frequency & $\%$ & Frequency & $\%$ \\
\hline 1 & Textbook support & 25 & 64.1 & 1 & 2.6 & 2 & 5.1 \\
\hline 2 & Providing means of transportation for the employees & 4 & 10.3 & 4 & 10.3 & 4 & 10.3 \\
\hline 3 & Medical care for the employees & 4 & 10.3 & 23 & 59 & 7 & 17.9 \\
\hline 4 & Holding various cultural meetings & 1 & 2.6 & 10 & 25.6 & 4 & 10.3 \\
\hline 5 & Encouraging students to participate in various student activities & 5 & 12.8 & 1 & 2.6 & 22 & 56.4 \\
\hline
\end{tabular}

Table 7 shows the three most important services provided by the Faculty to its members and the surrounding community and need improvement, as follows:

(a) Textbook support.

(b) Medical care for the employees.

(c) Encouraging students to participate in various student activities.

3.8 Internal/External Information Needed by the Faculty to Make the Best Choices for Initiatives or Actions

Table 8. Frequencies and percentages of the responses to (the three most important internal-external pieces of information that the Faculty needs to make the best choices in initiatives and actions)

\begin{tabular}{|l|l|l|l|l|l|l|l|}
\hline \multirow{2}{*}{ No. } & \multirow{2}{*}{ (Internal-External) Information } & \multicolumn{5}{|c|}{ Rank } \\
\cline { 3 - 8 } & & \multicolumn{2}{|c|}{ First } & \multicolumn{2}{|c|}{ Second } & \multicolumn{2}{c|}{ Third } \\
\cline { 3 - 9 } & & Frequency & $\%$ & Frequency & $\%$ & Frequency & $\%$ \\
\hline 1 & The external community's needs of different specializations & 27 & 69.2 & 3 & 7.7 & 2 & 5.1 \\
\hline 2 & Knowledge and skills to be provided to students to meet school needs & 4 & 10.3 & 27 & 69.2 & 1 & 2.6 \\
\hline 3 & $\begin{array}{l}\text { The most important technical services provided by the Faculty to } \\
\text { serve the community and develop the environment }\end{array}$ & 1 & 2.6 & 0 & 0 & 4 & 10.3 \\
\hline 4 & Mechanism of evaluating the performance of the faculty members & 1 & 2.6 & 2 & 5.1 & 1 & \\
\hline 5 & Distinctive scientific activities of the faculty members & 4 & 10.3 & 0 & 0 & 3 & 7.7 \\
\hline 6 & Research projects funded by international or local bodies & 1 & 2.6 & 4 & 10.3 & 25 & 64.1 \\
\hline 7 & $\begin{array}{l}\text { Criteria for screening, appointment, and promotion of administrative } \\
\text { leaders }\end{array}$ & 1 & 2.6 & 2 & 5.1 & 0 & 0 \\
\hline 8 & Criteria for preparing the university textbook & 0 & 0 & 1 & 2.6 & 3 & 7.7 \\
\hline
\end{tabular}




\section{Macrothink $\Lambda$ Institutem"}

Table 8 illustrates the three most important internal-external pieces of information that the Faculty needs to make the best choices in initiatives and actions, as follows:

(a) The external community's needs of different specializations.

(b) Knowledge and skills to be provided to students to meet school needs.

(c) Research projects funded by international or local bodies.

3.9 Individuals Who Do Outstanding Work and High Performance and You Want to Promote If You Are in Charge

Responses showed that some employees do outstanding work and deserve promotion and reward, especially in the absence of human resources at the Faculty. They are the ones in charge of the portal, the Quality Assurance Unit, the field training, as well as gardening and cleaning at the Faculty.

\subsection{New Services and Programs That the Faculty Can Implement Without Additional Costs} and Funds

Table 9. Frequencies and percentages of the responses to (the three most important new services and programs that can be implemented by the Faculty without additional costs and funds)

\begin{tabular}{|l|l|l|l|l|l|l|l|}
\hline \multirow{2}{*}{ No. } & \multirow{2}{*}{ New Services \& Programs } & \multicolumn{5}{c|}{ Rank } \\
\cline { 3 - 9 } & & \multicolumn{2}{|c|}{ First } & \multicolumn{3}{c|}{ Second } & \multicolumn{2}{c|}{ Third } \\
\cline { 3 - 9 } & & Frequency & $\%$ & Frequency & $\%$ & Frequency & $\%$ \\
\hline 1 & Developing distinguished programs & 27 & 69.2 & 1 & 2.6 & 0 & 0 \\
\hline 2 & Providing the means of transportation for the employees & 4 & 10.3 & 2 & 5.1 & 0 & 0 \\
\hline 3 & Improving medical care for employees & 1 & 2.6 & 28 & 71.8 & 2 & 5.1 \\
\hline 4 & Holding various cultural meetings & 2 & 5.1 & 2 & 5.1 & 0 & 0 \\
\hline 5 & Supporting student activities & 0 & 0 & 2 & 5.1 & 5 & 12.8 \\
\hline 6 & Establishing an advisory unit at the Faculty & 2 & 5.1 & 3 & 7.7 & 6 & 15.4 \\
\hline 7 & Professional development of graduates & 3 & 7.7 & 1 & 2.6 & 26 & 66.7 \\
\hline
\end{tabular}

Table 9 shows the three most important new services and programs that can be implemented by the Faculty without additional costs and funds, as follows:

(a) Developing distinguished programs.

(b) Improving medical care for employees.

(c) Professional development of graduates. 


\section{Discussion}

\subsection{Strengths of the Faculty of Education, Damietta University}

The item "the Faculty has a strategic plan approved by the Faculty Council" was ranked first and rated $(69.2 \%)$ because the strategic plan reveals the different opportunities or challenges encountered, making it more successful in taking advantage of the opportunities and more persistent in the face of changes. The item "the Faculty contains a quality assurance unit" was ranked second and rated (66.7\%) because the quality assurance unit plays a role in forming the future of the Faculty and achieving its competitiveness by spreading the culture of quality among the students and the staff, educating the faculty members, providing programs and courses, improving the formats of exam papers continuously according to the set criteria. Moreover, it plays a role in following up programs and courses, evaluating and analyzing their results, as well as reviewing, following up, and specifying programs, courses, and reports. The item "the website of the Faculty displays various services" was ranked third and rated $(56.4 \%)$ because the website displays different services, such as showing course schedules, exam schedules, seating numbers, examination halls, a repository of previous tests, and student results.

\subsection{Shortcomings and Weaknesses at the Faculty of Education}

The item "the Faculty of Education lacks mechanisms to follow up the implementation of the strategic plan" was ranked first and rated (61.5\%) because the importance of the implementation plan lies in the interest of stakeholders in the follow-up and development of each item of the plan. The development of plans without follow-up is not fruitful. Moreover, the tools and potentials of the Faculty should be taken into account to identify and overcome the serious obstacles. The item "the Quality Assurance Unit at the Faculty has not established integrated databases on its various activities" was ranked second and rated (59\%). This finding is consistent with the report of the field visit to the Faculty of Education, Damietta University on 19 and 20 December 2017. The item "the Faculty of Education does not use effective means to encourage and support the participation of the faculty members, teaching assistants, and students in activities, projects, and scientific conferences" was ranked third and rated (56.4\%). Many complex administrative issues limit the willingness of the staff of the Faculty of Education to participate. Thus, leaders should consider using strategic thinking to overcome former shortcomings and enhance competitiveness. The authors argue that the University Administration does not properly apply the scientific perspective that faculty members, assistants, and students help develop the strategic executive plan of the Faculty by attending relevant conferences, workshops, and courses. Accordingly, the future performance of the Faculty is poor. Based on the experience of the authors, some faculty members, assistants, and students have a relative weakness in the concept of strategic thinking due to poor training.

\subsection{Opportunities for the Faculty of Education Over the Next Two Years}

The item "the state encourages the development of distinguished programs" was ranked first and rated $(69.2 \%)$ in order to keep pace with recent trends and to meet the requirements of 
the labor market and the knowledge economy. The item "cultural agreements with local or international bodies should be employed" was ranked second and rated (59\%) because they offer scholarships to distinguished students and provide scientific and joint supervision missions. Moreover, the item "competitive projects for scientific research and funded by scientific institutions should be utilized" was ranked third and rated (61.5\%) because competitive projects adopt an idea to solve a specific problem with defined plans in terms of time, place, budget, and teamwork. Approvals shall be granted prior to the commencement of these projects. These projects are reviewed beforehand by specialized experts. After the approval of funding, they are also reviewed regularly to ensure their seriousness and continuity, as well as achieving objectives according to specific time plans. Therefore, the work system ensures serious competitiveness, commitment, creativity, competitiveness, and accountability, which is reflected positively in the scientific progress of the Faculty.

\subsection{Threats and Challenges Facing the Faculty of Education}

The item "decommissioning the graduates of the Faculty of Education" was ranked first and rated $(82.1 \%)$ because the Faculty has lost the outstanding students. The item "low achievement of students enrolled in the Faculty after completing the general secondary school" was ranked second and rated (69.2\%). Moreover, the item "recruitment of the faculty members, especially the outstanding ones, by Arab and foreign universities" was ranked third and rated (69.2\%) because of the lack of the attracting academic environment for the distinguished faculty members, which affects negatively the academic level of the Faculty.

\subsection{Issues That the Faculty Should Focus on to Accomplish Over the Next Two Years}

The item "developing outstanding programs" was ranked first and rated $(64.1 \%)$ to meet the requirements of the labor market and attract outstanding students. The item "accreditation of the programs offered at the Faculty" was ranked second and rated (61.5\%) because program accreditation helps the Faculty of Education meet the quality and accreditation standards, which is a global trend to ensure the quality of education and accreditation. Furthermore, the item "stimulating excellence in educational scientific research and international publishing" was ranked third and rated $(61.5 \%)$ because research excellence and international publishing are fundamental for the global ranking of universities. This result matches the findings of Young (2016) that strategic thinking is a future- oriented means of thinking.

\subsection{Personal Goals of the Faculty Members}

Most of the participants (75\%) reported that they seek to achieve the following goals this year: Participating in research projects for the advancement of the Faculty, preparing scientific research for international publication, activating the electronic scoring system, and establishing question banks for educational courses. It seems that these goals benefit the Faculty and achieve competitiveness.

\subsection{Services Provided by the Faculty to Its Employees and the Surrounding Community}

The item "textbook support" was ranked first and rated (64.1\%) because many students are unable to buy these books. Therefore, the Faculty of Education should pay attention to 
allocating budgets to the university textbooks. The item "medical care for the employees" was ranked second and rated (59\%). Furthermore, the item "encouraging students to participate in various student activities" was ranked third and rated (56.4\%) because student activities prepare students for work-life after graduation through the acquisition of various skills that help students demonstrate mature actions and increase their knowledge of the world. Accordingly, students can easily handle the components of society, invest leisure time in useful and healthy activities, and provide community services to break routine during the years of study. This result matches the findings of Goldman et al. (2015) that the practices of strategic thinking among leaders should be developed.

4.8 Internal/External Information Needed by the Faculty to Make the Best Choices for Initiatives or Actions

The item "the external community's needs of different specializations" was ranked first and rated $(69.2 \%)$ to prepare students to meet the needs of the labor market, including schools and various community institutions. The item "knowledge and skills to be provided to students to meet school needs" was ranked second and rated $(69.2 \%)$ to update the educational, training, and research systems at the Faculty of Education to provide students with the knowledge and skills required to meet the needs of the labor market (schools). Additionally, the item "research projects funded by international or local bodies" was ranked third and rated (64.1\%) to disseminate the culture of funded research projects and to make the best use of them in the university community. This result agrees with the findings of Pisapia and Robinson (2010) concerning the clarity of strategic thinking and interaction with external pressures for change.

\subsection{Individuals Who Do Outstanding Work and High Performance and You Want to Promote If You Are in Charge}

Most of the participants (75\%) report that some employees do outstanding work and deserve promotion and reward, especially in the absence of human resources at the Faculty. They are the ones in charge of the portal, the Quality Assurance Unit, the field training, as well as gardening and cleaning at the Faculty.

\subsection{New Services and Programs That the Faculty Can Implement Without Additional Costs and Funds}

The item "developing distinguished programs" was ranked first and rated (69.2\%). A team of the faculty members of the department can prepare a description of the program and its courses and obtain administrative approvals for the program. The item "improving medical care for employees" was ranked second and rated (71.8\%). It can be achieved through cooperation protocols with reputable and scientifically distinguished colleges of medicine. Furthermore, the item "professional development of graduates" was ranked third and rated $(66.7 \%)$. It can be achieved by holding training courses for graduates to develop them professionally and getting them familiar with the skills required by the labor market, including schools and other community institutions. This result agrees with the findings of Nuntamanop et al. (2013) concerning providing suggestions and perspectives of strategic 
thinking.

\section{Conclusion}

Based on the results of the questionnaire and the theoretical and field findings, the study concludes that adopting strategic thinking enables the leaders to guide the Faculty to have a different perspective of the internal and external dynamic factors and achieve success in the surrounding environment. The Faculty of Education, Damietta University has many practices of strategic thinking, including developing a strategic plan and having strategic vision, mission, and objectives. It also focuses on a set of issues related to its future and position. The authors argue that these issues are motivated by the university administration's keenness on formulating and publishing its mission clearly and easily. The mission can be accessed on the university's website and publications. This finding agrees with the results of Alaly (2014), Almarshad (2013), Aly (2018), Haycock et al. (2012), and Monnavarian et al. (2011) concerning introducing the reality and practice of strategic thinking.

\section{Recommendations}

Based on the reality of strategic thinking at the Faculty of Education, Damietta University and the conclusions, the study recommends,

(1) Make and follow up an updated action plan approved by the Faculty Council.

(2) Deliver training courses for the faculty members on the specification of educational programs, reports, syllabi, etc.

(3) Develop integrated databases on the various activities of the Faculty's Quality Assurance Unit.

(4) Take formal actions for periodic internal and external reviews of educational programs and syllabi.

(5) Utilize the reports of internal and external reviewers of educational programs and syllabi in the development of educational programs.

(6) Market the distinguished programs by various means.

(7) Hold workshops and training courses based on an annual program that fosters strategic thinking with the support of the university administration to this trend.

(8) The workshops and training programs should focus on the comprehensive perspective, the internal environment (weaknesses and strengths), and the external environment (threats and opportunities) of the university.

(9) Develop clear missions and objectives among university leaders to promote their participation and encourage others to apply them.

(10) Offer training programs to university leaders to train them in the concept and importance of strategic thinking to adjust to environmental variables.

(11) Allow university leaders to invest funding by community institutions and members 
to develop education and achieve competitiveness with other universities.

(12) Approve an award to the university with a distinguished strategy whose leaders play a considerable role in developing administration and seize available opportunities to increase competitiveness with other universities.

(13) Use the means of effective dialog among employers to identify their opinions and suggestions about the future vision of their universities.

(14) Form and reward committees to analyze the internal and external environments of the university.

\section{References}

Al'Attar, S., \& Afifi, S. (2017). Skills of strategic thinking, decision making, and professional counseling to confront unemployment. Paper presented at the 11th Arab Scientific Conference (8th International) Education and Self-Employment Culture, from Laxity to Brotherhood, Culture Association for Development, Sohag University, and Academy of Scientific Research, Egypt.

Alaly, A. (2014). The degree of practicing strategic thinking styles among heads of departments at applied colleges in Kuwait and its relationship with re-engineering of administrative processes from the point of view of faculty members (MA thesis, Faculty of Educational Sciences, Middle East University, Jordan).

Al-Amiri, A., \& Kassir, H. (2017). Relationship between strategic thinking and job performance of mid-level managers: A field study on Islamic Banks in the Yemeni Capital Sana'a. Journal of Social Studies, 23(3), 53-74. https://doi.org/10.20428/JSS.23.3.3

Alasmar, N. (2008). Strategic thinking (patterns-practices-obstacles) among the female principals of mainstream schools in Jeddah (MA thesis, College of Education, Umm Al-Qura University, Saudi Arabia).

Alebbini, T. (2018). Strategic thinking and its impact on achieving organizational excellence: A case study of the Social Security Cooperation ( $\mathrm{PhD}$ dissertation, Faculty of Graduate Studies, The World Islamic Sciences and Education University, Oman, Jordan).

Al-Hamdani, S., \& Al-Khulani, M. (2018). The effect of strategic thinking in improving the quality of professional life. Arab Journal of Administration, 38(2), 211-229.

Al-Khara'an, A. (2018). The degree of practicing strategic thinking patterns among the educational directors in the Saudi educational department. Scientific Journal of the Faculty of Education-Assiut University, 34(4), 439-470.

Almarshad, M. (2013). Strategic thinking in Jordanian publicly quoted companies (PhD dissertation, University of Huddersfield, London).

Aly, M. (2018). The degree of practicing strategic thinking patterns among the educational leaders of Tikrit University: A comparative study between the scientific and humanities colleges. AL GHAREE for Economics and Administration Sciences, 15(4), 661-680. 
Ashammari, G., \& Akhras, N. (2017). Strategic thinking \& its relationship with the big five personality traits among the heads of academic departments at Jouf University. Journal of Educational \& Psychological Sciences, 18(3), 447-475. https://doi.org/10.12785/JEPS/ 180315

Damietta University. (2015). Self-study report. Retrieved from http://www.du.edu.eg/upFiles Center/uni/1453207878.pdf

Damietta University. (2019). Statistics of the faculty members at the Faculty of Education. Egypt: Damietta University.

Dushkov, G. (2018). Strategic thinking key for future success in organization. International Journal of Recent Scientific Research, 9(5), 26675-26678.

Elanzi, A., \& Akhras, N. (2010). Strategic thinking and its obstacles among the principals of government primary schools in Arar City, Kingdom of Saudi Arabia. Journal of the Faculty of Education-Al-Azhar University, 144(1), 431.

El-Balawi, A. (2016). The impact of strategic thinking on the effectiveness of crisis management: a case study on the Saudi Telecom Company. Journal of the Faculty of Education-Al-Azhar University, 171(35), 531-596. https://doi.org/10.21608/jsrep.2016.49209

Elfarra, M. (2009). Level of strategic thinking among the leaders of non-governmental organizations in the Gaza Strip. Tanmiyat Al-Rafidain, 31(95), 33-59. https://doi.org/ 10.33899/tanra.2009.161795

Emran, F., \& Emamgholizadeh, S. (2015). Strategic thinking and approaches. Journal of Applied Environmental and Biological Sciences, 5(11), 145-150.

Faculty of Education, Damietta University. (2019a). Vision. Retrieved from http://edu.du.edu.eg/Unit/Details/37/144

Faculty of Education, Damietta University. (2019b). Mission. Retrieved from http://edu.du.edu.eg/Unit/Details/37/145

Faculty of Education, Damietta University. (2019c). Strategic objectives. Retrieved from http://edu.du.edu.eg/Unit/Details/37/143

Goldman, E., Scott, A., \& Follman, J. (2015). Organizational practices to develop strategic thinking. Journal of Strategy and Management, 8(2), 155-175. https://doi.org/10.1108/ JSMA-01-2015-0003

Haycock, K., Cheadle, A., \& Bluestone, K. (2012). Strategic thinking: Lessons for leadership from the literature. Library Leadership and Management, 26(3), 1-23. Retrieved from https://journals.tdl.org/llm/index.php/llm/article/download/2635/6096

Khalafallah, M. (2015). Managing talents in the Faculty of Education at Al-Aqsa University and its relation to the strategic thinking indicators for high leadership from the perspectives of teaching staff. Journal of the Association of Arab Universities for Research in Higher Education, 35(1), 93-112. 


\section{Macrothink}

Ministry of Higher Education. (2005). Internal regulations (two-semester system). Egypt: Ministry of Higher Education.

Mohamed, A. (2011). Strategic educational planning: Theory and practice. Oman: Dar Al-Massira.

Monnavarian, A., Farmani, G., \& Yajam, H. (2011). Strategic thinking in Benetton. Strategy Series, 12(2), 63-72. https://doi.org/10.1108/17515631111114868

Muriithi, S., Louw, L., \& Radloff, S. (2018). The relationship between strategic thinking and leadership effectiveness in Kenyan indigenous banks. South African Journal of Economic and Management Sciences, 21(1), 1-11. https://doi.org/10.4102/sajems.v21i1.1741

Nuntamanop, P., Kauranen, I., \& Igel, B. (2013). A new model of strategic thinking competency. Journal of Strategy and Management, 6(3), 242-264. https://doi.org/10.1108/ JSMA-10-2012-0052

Pisapia, J., \& Robinson, D. (2010). Transforming the academy: Strategic thinking and/or strategic planning? Paper presented at the 4th International Conference, the American Institute of Higher Education, Virginia, USA.

Steptoe-Warren, G., Howat, D., \& Hume, I. (2011). Strategic thinking and decision making: Literature review. Journal of Strategy and Management, 4(3), 238-250. https://doi.org/ $10.1108 / 17554251111152261$

Young, L. (2016). Towards a more comprehensive understanding of strategic thinking. Australian Defence Force Journal, 199, 55-64.

\section{Copyright Disclaimer}

Copyright for this article is retained by the author(s), with first publication rights granted to the journal.

This is an open-access article distributed under the terms and conditions of the Creative Commons Attribution license (http://creativecommons.org/licenses/by/3.0/). 